J. Dairy Sci. 96:3857-3866

http://dx.doi.org/10.3168/jds.2012-6117

(C) American Dairy Science Association ${ }^{\circledR}, 2013$.

\title{
The effect of starch-, fiber-, or sugar-based supplements on nitrogen utilization in grazing dairy cows
}

\author{
R. J. Higgs, ${ }^{* 1}$ A. J. Sheahan, $†$ K. Mandok, $†$ M. E. Van Amburgh, ${ }^{*}$ and J. R. Roche† \\ *Department of Animal Science, Cornell University, Ithaca, NY 14853 \\ †DairyNZ Limited, Private Bag 3221, Hamilton 3240, New Zealand
}

\section{ABSTRACT}

Nitrogen utilization in grazing cows is often low due to high concentrations of rapidly soluble and degradable protein in the pasture-based diet. Broadly, opportunities to improve $\mathrm{N}$ utilization lie in either reducing the amount of $\mathrm{N}$ consumed by the animal, or incorporating more $\mathrm{N}$ into milk protein. The goal of this study was to compare the relative importance of dietary $\mathrm{N}$ intake and productive $\mathrm{N}$ output for improving $\mathrm{N}$ utilization in grazing cows fed either starch-, fiber-, or sugar-based supplements. Also, the Cornell Net Carbohydrate and Protein System (CNCPS; Cornell University, Ithaca, NY) was evaluated as a tool to assess cow performance and improve $\mathrm{N}$ utilization in pasture-based systems. Eighty-five cows were randomly assigned to 1 of 5 treatments at parturition (17 cows per treatment). Treatments consisted of a pasture-only control and pasture with a starch- (St and StN), fiber- $(\mathrm{FbN})$, or a sugar-based supplement. The StN and FbN treatments contained additional dietary N. Diets were formulated using the CNCPS to supply similar levels of dietary metabolizable energy, but differing levels of dietary $\mathrm{N}$ and metabolizable protein. Nitrogen utilization ranged from 22 to $26 \%$ across the 5 groups. Cows fed the St diet had the lowest levels of milk urea N, blood urea N, and urinary $\mathrm{N}$ excretion and had the highest productive $\mathrm{N}$ output $(149 \mathrm{~g} / \mathrm{d})$. Cows fed the FbN treatment had similar productive $\mathrm{N}$ output $(137 \mathrm{~g} / \mathrm{d})$ and consumed approximately $100 \mathrm{~g} / \mathrm{d}$ more dietary $\mathrm{N}$ than the $\mathrm{St}$ treatment, resulting in greater urinary $\mathrm{N}$ excretion. Although milk protein yield was moderately greater in the St treatment, quantitatively the difference in $\mathrm{N}$ intake $(100 \mathrm{~g} / \mathrm{d})$ had the greatest effect on $\mathrm{N}$ utilization and suggests that controlling dietary $\mathrm{N}$ intake should be the first priority when attempting to improve $\mathrm{N}$ utilization in grazing cows. No effect was observed of supplementing pasture-fed cattle with sugar on production or $\mathrm{N}$ utilization under the conditions of this experiment.

Received September 3, 2012.

Accepted February 4, 2013.

${ }^{1}$ Corresponding author: rjh257@cornell.edu
Predictions of metabolizable energy and protein availability for milk yield from the CNCPS were similar to actual milk yield for all treatments. Model-predicted N utilization and excretion reflected the trends observed in the measured data and suggests that the CNCPS can be a useful tool for formulating and evaluating diets to improve $\mathrm{N}$ utilization in pasture-based systems.

Key words: modeling, pasture, nitrogen-use efficiency, sustainability

\section{INTRODUCTION}

Globally, increased pressure exists to reduce the environmental impact of dairying. Nitrogen management is of particular concern in pasture-based systems due to its impact on water quality in aquifers, rivers, and lakes (Ledgard et al., 1999). Improving $\mathrm{N}$ utilization in pastoral systems presents a unique set of challenges, given the requirement for high levels of pasture consumption for low-cost production, the large demands of $\mathrm{N}$ by temperate grasses, and the resultant soluble and rapidly degradable nature of pasture protein (Kolver, 2003).

Nitrogen-use efficiency can be broadly defined as the proportion of productive $\mathrm{N}$ output from the cow ( $\mathrm{N}$ accretion, milk $\mathrm{N}$, or $\mathrm{N}$ retained by the conceptus), relative to total $\mathrm{N}$ consumed (Calsamiglia et al., 2010). An increase in milk protein yield would increase productive $\mathrm{N}$ output and improve $\mathrm{N}$ utilization for a given $\mathrm{N}$ intake. Any $\mathrm{N}$ not secreted in milk, or accreted into tissue, will be lost in either feces or urine (Lapierre and Lobley, 2001). Fecal N is relatively fixed (Marini and Van Amburgh, 2003); the greatest opportunity to improve $\mathrm{N}$ utilization, therefore, is in either reducing urinary $\mathrm{N}$ output, or increasing productive $\mathrm{N}$ output (Broderick, 2003; Marini and Van Amburgh, 2003). In pasture-based systems, previous efforts to improve $\mathrm{N}$ capture have focused on improving energy supply to the rumen, with the objective of incorporating more ammonia into microbial protein and, thereby, increasing the AA flow to the small intestine (Kolver et al., 1998a; Miller et al., 2001; Sairanen et al., 2005; Moorby et al., 2006). Although important, this assumes that the milk 
yield of the cow is limited by AA supply, which when corrected, should increase milk protein synthesis and secretion. Milk protein synthesis appears more closely linked to milk yield, physiological state, and overall nutritional status than simple substrate availability (Hanigan et al., 2001; Cant et al., 2003). Therefore, in a situation where MP is adequate, increasing AA supply will increase hepatic removal and shift the majority of the associated $\mathrm{N}$ back to the urea pool with no real benefit to overall $\mathrm{N}$ utilization (Lapierre et al., 2005).

Changing the ratio of starch or sugar to NDF has previously been reported to alter ruminal VFA profiles (Bauman et al., 1971; Beckman and Weiss, 2005), with subsequent effects on milk composition (Broderick, 2003; Beckman and Weiss, 2005). Changing dietary $\mathrm{MP}$ and $\mathrm{N}$ intake simultaneously tests the effect of substrate supply, dietary $\mathrm{N}$ dilution, and their comparative importance in improving $\mathrm{N}$ utilization for a given $\mathrm{N}$ intake compared with increasing productive $\mathrm{N}$ output. The Cornell Net Carbohydrate and Protein System (CNCPS; Cornell University, Ithaca, NY) was previously used to evaluate grazing cows by Kolver et al. (1998b), who reported that the model could realistically predict ME and MP supply and subsequent milk production. Recent changes have been made to improve CNCPS predictions, including a recharacterization of various pool constituents, degradation rates, passage rate assignments (Van Amburgh et al., 2007, 2010), and predictions of $\mathrm{N}$ excretion (Higgs et al., 2012). The aim of the current study was to investigate the opportunity to improve productive $\mathrm{N}$ output in grazing cows using starch-, fiber-, and sugar-based supplements formulated to supply balanced ME, with differing MP and $\mathrm{N}$ intakes. A second goal was to simulate the experimental conditions in the CNCPS and assess its usefulness as a tool to model $\mathrm{N}$ utilization under grazing conditions.

\section{MATERIALS AND METHODS}

Experimental work was conducted at the DairyNZ Lye Farm (Hamilton, New Zealand; $37^{\circ} 47^{\prime} \mathrm{S} 175^{\circ} 19^{\prime} \mathrm{E}$ ) during July and August 2010. Prior approval for animal use was attained from the Ruakura Animal Ethics Committee (Hamilton, New Zealand).

\section{Experimental Design and Treatments}

Eighty-five dairy cows (53 Friesian and 32 Friesian $\times$ Jersey; 69 multiparous and 16 primiparous) due to calve over a 21 -d period were randomly assigned to 1 of 5 treatments at parturition $(\mathrm{n}=17)$; treatments were balanced for milk production (mean of the first 100 DIM from the previous lactation for multiparous cows; $17.7 \pm 0.7 \mathrm{~kg}$ of milk/cow per day; mean $\pm \mathrm{SD}$ ), precalving BW $(549 \pm 29 \mathrm{~kg}), \mathrm{BCS}(4.5 \pm 0.3 ; 10$-point scale; Roche et al., 2004), and age $(4.5 \pm 0.2 \mathrm{yr})$.

Dietary treatments consisted of a pasture-only control $(\mathbf{C O N})$ and pasture with starch (St and $\mathbf{S t N})$, fiber $(\mathbf{F b N})$, or sugar $(\mathbf{S g})$-based supplements. The StN and $\mathrm{FbN}$ treatments were formulated to supply equal dietary $\mathrm{N}$ and MP, whereas the St and Sg treatments had no additional N. A small amount of soybean meal was added to the $\mathrm{StN}$ treatment to make it equivalent to the $\mathrm{FbN}$ treatment on a true-protein ( $\mathbf{T P})$ basis. Corn grain was used as the starch source, wheat middlings as the fiber source, and molasses as the sugar source. Supplements were formulated using the CNCPS v6.1 (Tylutki et al., 2008; Van Amburgh et al., 2010) and fed to support a target of $30 \mathrm{~kg}$ of milk. Chemical composition and DMI for each treatment are presented in Table 1. All supplements were offered in pellet form except the $\mathrm{Sg}$ treatment, which was in liquid form and fed at a lower rate to prevent adverse health effects. The assumptions used when formulating the supplements were that cows in early lactation $(\sim 40 \mathrm{DIM})$, of similar BW, offered between 30 and $40 \mathrm{~kg}$ of ryegrass-based pasture $\mathrm{DM} / \mathrm{d}$ would consume approximately $15 \mathrm{~kg}$ of DM/d (Dalley et al., 1999) and would substitute approximately $0.5 \mathrm{~kg}$ of pasture DM $/ \mathrm{kg}$ of concentrate DM fed (Bargo et al., 2003). Supplements were introduced gradually over a 3 -d period and offered in 2 equal portions at a.m. and p.m. milkings. The Sg treatment was provided orally in a diluted bolus (3:1 molasses:water) after each milking. All cows calved in an 18-d period and started their allocated treatment immediately after parturition. The experiment concluded on the same day for all cows meaning the experimental period ranged from 6.5 to 9 wk, depending on the calving date.

\section{Grazing Management}

Cows rotationally grazed 37 ha permanently subdivided into 1-ha paddocks (defined grazing area) as one group $(\mathrm{n}=85)$. Each paddock was further subdivided using a temporary electric fence to establish grazing conditions that encouraged pasture to be harvested to a postgrazing residual mass of 1,500 to $1600 \mathrm{~kg}$ of $\mathrm{DM} /$ ha. This has been reported to balance the dual goals of achieving high DMI while maximizing pasture production and quality for future grazing events (Hoogendoorn et al., 1992; Lee et al., 2008). Cows in early lactation have increasing DMI; therefore, pasture allowance was continually reassessed to maintain the target residual pasture mass. Pasture allowance (mean $\pm \mathrm{SD}$ ) was $29 \pm 5 \mathrm{~kg}$ of DM/cow per day for the last 3 wk of the study. Pre- and postgrazing compressed sward heights for the same period were $22.9 \pm 2.3$ and $10.6 \pm 1.2 \mathrm{~cm}$, respectively, and pre- and postgrazing 
Table 1. Feed intake and chemical composition of experimental diets

\begin{tabular}{|c|c|c|c|c|c|}
\hline \multirow[b]{2}{*}{ Item $^{1}$} & \multicolumn{5}{|c|}{$\operatorname{Diet}^{2}$} \\
\hline & $\mathrm{CON}$ & St & StN & $\mathrm{FbN}$ & $\mathrm{Sg}$ \\
\hline \multicolumn{6}{|l|}{ Intake $(\mathrm{kg} / \mathrm{d})$} \\
\hline DMI & 11.7 & 13.8 & 13.9 & 15.1 & 12.6 \\
\hline \multicolumn{6}{|l|}{ Ingredient ( $\%$ of $\mathrm{DM})$} \\
\hline Pasture & 100.0 & 72.2 & 78.4 & 68.7 & 86.7 \\
\hline Corn meal & 0.0 & 25.0 & 16.7 & 0.0 & 0.0 \\
\hline Wheat middlings & 0.0 & 2.8 & 2.2 & 29.8 & 0.0 \\
\hline Soybean meal, $48 \%$ & 0.0 & 0.0 & 1.8 & 0.0 & 0.0 \\
\hline Fat & 0.0 & 0.0 & 0.0 & 1.1 & 0.0 \\
\hline Urea & 0.0 & 0.0 & 0.9 & 0.4 & 0.0 \\
\hline Molasses & 0.0 & 0.0 & 0.0 & 0.0 & 13.3 \\
\hline \multicolumn{6}{|c|}{ Chemical composition (\% of DM) } \\
\hline $\mathrm{CP}$ & 28.1 & 23.0 & 27.3 & 25.0 & 25.0 \\
\hline $\mathrm{SP}(\%$ of $\mathrm{CP})$ & 46.0 & 41.4 & 42.9 & 45.7 & 53.0 \\
\hline ADICP ( $\%$ of $\mathrm{CP}$ ) & 7.9 & 6.5 & 6.8 & 6.6 & 7.2 \\
\hline NDICP (\% of CP) & 33.3 & 26.9 & 28.1 & 26.8 & 29.3 \\
\hline NDF & 39.5 & 32.6 & 34.0 & 38.5 & 34.3 \\
\hline $\mathrm{ADF}$ & 22.0 & 17.5 & 18.5 & 19.1 & 19.1 \\
\hline Lignin (\% of NDF) & 5.7 & 8.1 & 7.2 & 6.9 & 13.8 \\
\hline $\mathrm{EE}$ & 4.9 & 4.6 & 4.6 & 5.7 & 4.6 \\
\hline Starch & 0.3 & 16.5 & 11.3 & 7.1 & 0.3 \\
\hline Sugar & 12.8 & 10.2 & 10.9 & 10.4 & 21.8 \\
\hline Ash & 8.0 & 6.4 & 6.8 & 6.9 & 8.6 \\
\hline
\end{tabular}

pasture yield was $3,243 \pm 261$ and $1,681 \pm 233 \mathrm{~kg}$ of $\mathrm{DM} /$ ha, respectively (mean $\pm \mathrm{SD}$ ). Measurements were made using a rising plate meter installed with an electronic counter (Farmworks Ltd., Palmerston North, New Zealand). Cows had access to a fresh allocation of pasture twice daily and only returned to the same area when a minimum of 2 leaves had appeared on the majority $(>66 \%)$ of perennial ryegrass (Lolium perenne L.) tillers. The pasture offered consisted of (mean \pm SD) $90.2( \pm 2.8) \%$ perennial ryegrass leaf, $2.5( \pm 1.4) \%$ perennial ryegrass stem, $1.5( \pm 2.2) \%$ white clover (Trifolium repens), $0.6( \pm 0.7) \%$ weeds (Sisymbrium officinale, Achillea millefolium, Taraxacum officinale, and Ranunculus sardous), and $5.2( \pm 1.8) \%$ dead material, on a DM basis.

\section{Pasture Measurements}

Representative samples of pasture were collected daily by clipping pasture to grazing height from paddocks due to be grazed. Samples were bulked on a weekly basis for the duration of the experiment, and duplicate samples were dried for $48 \mathrm{~h}$ at either $100^{\circ} \mathrm{C}$ for $\mathrm{DM}$ analysis or $60^{\circ} \mathrm{C}$ for analysis of nutrient composition. Samples dried at $60^{\circ} \mathrm{C}$ were subsequently ground to pass through a $1.0-\mathrm{mm}$ sieve (Christy laboratory mill; Christy Turner Ltd., Suffolk, UK) and analyzed by wet chemistry for the nutrients required to evaluate the diets in the CNCPS (Tylutki et al., 2008; DairyOne, Ithaca, NY).

\section{Animal Measurements}

DMI. Mean group pasture DMI was calculated as the product of the difference between the pre- and postgrazing pasture mass and area grazed daily (Roche et al., 1996). Supplement offered and refused was measured at each milking. Estimations of individual cow pasture DMI were obtained using the $n$-alkane technique outlined by Kennedy et al. (2003). Briefly, each cow was dosed twice daily (at milking) with a capsule containing $356 \mathrm{mg}$ of $n$-dotriacontane (C32; i.e., 712 $\mathrm{mg}$ of $\mathrm{C} 32 /$ cow per day) for a 10-d period in wk 6 and 7 of the experiment. Fecal grab samples were collected twice daily from each cow (after milking) during the last $5 \mathrm{~d}$ of the $10-\mathrm{d}$ period. Fecal samples from each cow for the 5 -d period were bulked and stored at $-17^{\circ} \mathrm{C}$ awaiting alkane analysis. During the same 5-d period, pasture samples were plucked to grazing height, following close observation of the grazing animal, to represent pasture grazed. The $n$-alkane concentration (C25-C36) in pasture, supplement, and feces were determined using gas chromatography (Mayes et al., 1986). The ratio of pasture C33 (tritriacontane) to dosed C32 (n-dotria- 
contane) was used to estimate pasture DMI. Estimates of daily pasture DMI were calculated as follows:

$$
\begin{aligned}
& \text { Daily pasture intake }(\mathrm{kg} \text { of DM/cow }) \\
& =\frac{\mathrm{F}_{\mathrm{i}} / \mathrm{F}_{\mathrm{j}} \times\left(\mathrm{D}_{\mathrm{j}}+\mathrm{I}_{\mathrm{s}} \times \mathrm{S}_{\mathrm{j}}\right)-\mathrm{I}_{\mathrm{s}} \times \mathrm{S}_{\mathrm{i}}}{\mathrm{P}_{\mathrm{i}}-\left(\mathrm{P}_{\mathrm{j}} \times \mathrm{F}_{\mathrm{i}} / \mathrm{F}_{\mathrm{j}}\right)}
\end{aligned}
$$

where $\mathrm{F}_{\mathrm{i}}, \mathrm{S}_{\mathrm{i}}$, and $\mathrm{P}_{\mathrm{i}}$ are the concentrations $(\mathrm{mg} / \mathrm{kg}$ of $\mathrm{DM}$ ) of the natural odd-chain $n$-alkane (C33) in feces, supplement, and pasture, respectively; $F_{j}, S_{j}$, and $P_{j}$ are the concentrations $(\mathrm{mg} / \mathrm{kg}$ of $\mathrm{DM})$ of the dosed even-chain $n$-alkane (C32) in feces, supplements, and pasture, respectively; and $D_{j}$ and $I_{S}$ are the dose rate $(\mathrm{mg} / \mathrm{d})$ of the even-chain $n$-alkane (C32) and supplement intake, respectively.

Milk and $\boldsymbol{B} \boldsymbol{W}$. Individual milk yields were recorded daily (GEA Westfalia Separator GmbH, Oelde, Germany). Fat, TP, and lactose concentrations in milk were determined by a MilkoScan FT120 (Foss Electric A/S, Hillerød, Denmark) on a composite from a.m. and p.m. samples collected once ( 2 consecutive days) each week for the duration of the experiment. Milk composition data were verified by reference techniques for a subset of milk samples (milk fat: Röese-Gottlieb method; IDF, 1987; CP: Kjeldahl techniques; Barbano et al., 1991). Body weight and BCS were measured weekly following the a.m. milking; BCS was assessed on a 10-point scale, where 1 is emaciated and 10 is obese (Roche et al., 2004). These scores can be converted to the 5-point scale of Wildman et al. (1982) using the regression equation generated by Roche et al. (2004; 5-point BCS $=1.5+0.32$ 10-point BCS).

Blood. Two 10-mL evacuated blood tubes containing either a sodium heparin pellet (158 IU of sodium heparin) or EDTA (0.117 mL of $\left.15 \% \mathrm{~K}_{3} \mathrm{EDTA}\right)$ to prevent coagulation were collected from each cow by coccygeal venipuncture before treatment allocation and weekly thereafter. Plasma was separated $(1,120 \times g$ for $10 \mathrm{~min}$ at $4^{\circ} \mathrm{C}$ ) and frozen at $-20^{\circ} \mathrm{C}$ before analysis. Plasma from the EDTA tubes was analyzed for $\mathrm{NH}_{3}$ concentration (mmol/L), based on the enzymatic kinetic assay described by da Fonseca-Wollheim (1973). Plasma from the sodium heparin tubes were analyzed for NEFA, BHBA, glucose, and urea. Determination of NEFA (mmol/L; colorimetric method using a commercial kit: Wako Pure Chemical Industries Ltd., Osaka, Japan), BHBA (mmol/L; BHBA dehydrogenase assay based on formation of acetoacetate and NADH after addition of NAD), glucose (mmol/L; hexokinase method based on formation of NADPH), and urea $(\mathrm{mmol} / \mathrm{L}$; urease hydrolysis method) concentrations were performed on a Hitachi Modular P800 analyzer (Roche, Basel, Switzerland) at $30^{\circ} \mathrm{C}$ by Gribbles Veterinary Pathology Ltd. (Hamilton, New Zealand). The inter- and intraassay coefficients of variation were $<2 \%$ for all assays.

Urine. Mid-stream urine samples were collected once each week during voluntary urination of cows immediately before the morning milking. After collection, samples were divided into 50-mL aliquots for the analysis of creatinine, urea, uric acid, allantoin, urea, and total N. The aliquots used for the analysis of urea and total $\mathrm{N}$ were reduced to $\mathrm{pH} \leq 2$ using approximately $3 \mathrm{~mL}$ of $6 \mathrm{~mol}$ of hydrochloric acid/L and frozen at $-20^{\circ} \mathrm{C}$ before analysis. Creatinine, uric acid $(\mathrm{mmol} / \mathrm{L}$; enzymatic colorimetric assay), and urea ( $\mathrm{mmol} / \mathrm{L}$; kinetic UV assay) were analyzed using commercial kits (Roche Diagnostic NZ Ltd., Auckland, New Zealand) by Gribbles Veterinary Pathology Ltd. Allantoin was analyzed on a spectrophotometer using a colorimetric assay (Young and Conway, 1942) and total $\mathrm{N}$ was analyzed using the Leco total combustion method (Institute of Food, Nutrition and Human Health, Massey University, New Zealand).

\section{CNCPS Inputs}

Data used in the CNCPS represented the mean of a 5 -d period in wk 7 of the study, coinciding with the $n$-alkane DMI estimation. Dietary inputs, including DMI, feed ingredients, and the chemical composition of ration are in Table 1. Animal inputs, including milk production, initial BCS, and BW change are presented in Table 2. Other inputs, including stage of lactation, breed, and parity are consistent with the previous description in this section. The contribution of tissue mobilization to predictions of $\mathrm{ME}$ and MP milk (Table 2) were estimated from BW change. The chemical composition (fat:protein) of mobilized body reserves changes depending on the BCS of the animal (Fox et al., 1999). To account for this, the composition of reserves mobilized was calculated using the BW change and initial BCS from Table 2 and equations in Fox et al. (2004). Briefly, initial BW and BCS were used to calculate a reference BW at BCS 3 (1-5 scale). Mobilized fat and protein were then estimated using the reference $\mathrm{BW}$ and the change from initial to final BW (Fox et al., 2004). Change in BW was preferred to BCS as an estimate of tissue mobilization due to the difficulty in ascertaining small changes in BCS over 1 time period (Ferguson et al., 1994). It was assumed that when MP supply was in excess to requirements, protein mobilized from tissue was used as an energy source and contributed to ME supply. 
Table 2. Cornell Net Carbohydrate and Protein System (CNCPS; Cornell University, Ithaca, NY) inputs and predictions for the effect of supplementing different carbohydrate types on $\mathrm{N}$ use parameters

\begin{tabular}{|c|c|c|c|c|c|}
\hline \multirow[b]{2}{*}{ Item } & \multicolumn{5}{|c|}{ Diet $^{1}$} \\
\hline & $\mathrm{CON}$ & St & StN & $\mathrm{FbN}$ & $\mathrm{Sg}$ \\
\hline Milk, actual $(\mathrm{kg} / \mathrm{d})$ & 23 & 28 & 26 & 26 & 24 \\
\hline ME milk, predicted ${ }^{2}(\mathrm{~kg} / \mathrm{d})$ & 22 & 27 & 27 & 28 & 26 \\
\hline MP milk, predicted ${ }^{2}(\mathrm{~kg} / \mathrm{d})$ & 23 & 25 & 26 & 27 & 24 \\
\hline Diet-allowable ME milk $(\mathrm{kg} / \mathrm{d})$ & 7 & 15 & 14 & 15 & 10 \\
\hline Diet-allowable MP milk ${ }^{3}(\mathrm{~kg} / \mathrm{d})$ & 23 & 24 & 26 & 27 & 24 \\
\hline Initial BW (kg) & 441 & 467 & 442 & 448 & 477 \\
\hline Final BW (kg) & 417 & 449 & 422 & 427 & 453 \\
\hline Initial $\mathrm{BCS}^{4}$ & 3.8 & 4.1 & 3.8 & 4.0 & 4.1 \\
\hline Final BCS & 3.7 & 4.0 & 3.7 & 4.0 & 4.0 \\
\hline $\mathrm{N}$ intake $(\mathrm{g} / \mathrm{d})$ & 527 & 507 & 607 & 604 & 504 \\
\hline Productive N (g/d) & 116 & 149 & 134 & 137 & 115 \\
\hline Fecal N (g/d) & 155 & 163 & 182 & 187 & 155 \\
\hline Urine N (g/d) & 303 & 230 & 331 & 320 & 279 \\
\hline $\mathrm{N}$ balance $(\mathrm{g} / \mathrm{d})$ & -48 & -34 & -39 & -40 & -45 \\
\hline MP intake $(\mathrm{g} / \mathrm{d})$ & 1,548 & 1,697 & 1,776 & 1,889 & 1,547 \\
\hline MP from bacteria ( $\%$ of MP intake) & 34 & 42 & 38 & 38 & 40 \\
\hline ME intake $(\mathrm{MJ} / \mathrm{d})$ & 123 & 154 & 151 & 159 & 136 \\
\hline Productive N:urine N & 0.38 & 0.65 & 0.40 & 0.43 & 0.41 \\
\hline Productive N:intake N & 0.22 & 0.29 & 0.22 & 0.23 & 0.23 \\
\hline Milk TP:MP supply ${ }^{5}$ & 0.48 & 0.56 & 0.48 & 0.46 & 0.47 \\
\hline
\end{tabular}

${ }^{1} \mathrm{CON}=$ control (pasture only); $\mathrm{St}=$ pasture with a starch-based supplement; StN = pasture with a starchbased supplement and additional $\mathrm{N} ; \mathrm{FbN}=$ pasture with a fiber-based supplement and additional $\mathrm{N} ; \mathrm{Sg}=$ pasture with a sugar-based supplement.

${ }^{2}$ Includes contributions from body reserves.

${ }^{3} \mathrm{ME}$ and MP milk refer to the potential milk that could be produced at the predicted supply of metabolizable energy and metabolizable protein (ME and MP) by the CNCPS.

${ }^{4}$ Measured on a 1 to 10 scale (Roche et al., 2004).

${ }^{5} \mathrm{TP}=$ true protein.

\section{Statistical Analysis}

Data are expressed as means of the last $3 \mathrm{wk}$ of the study and were analyzed using a restricted maximum likelihood model (REML) in GenStat 13.2 (VSN International, 2010). The model included the fixed effects of calving group (3 groups to account for calving date), age (primiparous and multiparous), week of study, treatment, and the interaction of calving group and week. The effects of calving group, parity, and week of study were included to account for nontreatment variation and are not considered important in explaining treatment effects. Cow was included as a random effect. Treatment effects were considered significant at $P<0.05$. The least significant difference for the error degrees of freedom was approximately $2 \times$ the standard error of the difference.

\section{RESULTS}

\section{Animal Observations}

The type of supplement fed to cattle on treatment affected milk yield $(P<0.01)$, yield of TP $(P<0.001)$ and lactose $(P<0.01)$, but not milk fat (Table 3 ). Cows fed the St diet had the highest milk and TP yields $(P<0.01)$, followed by those fed the FbN and StN diets. Cows fed the Sg diet had similar milk and milk components to cows fed the CON diet. Concentrations of fat, TP, and lactose were affected $(P<0.01)$ by treatment (Table 3). Milk fat concentration was lower in cows fed the St supplement than in cows in the other 4 groups, which did not differ from each other. True protein concentration was greater $(P<0.01)$ in the St treatment compared with the CON and Sg treatments, but similar to the $\mathrm{StN}$ and FbN treatments. Milk urea $\mathrm{N}$ concentration was lower in cows fed the St $\operatorname{diet}(P<$ 0.001) compared with all other diets.

Cows fed the St diet had more than $1 \mathrm{mmol} / \mathrm{L}$ less urea in blood than the other treatments, which was consistent with the ratios of urinary urea to creatinine and urinary $\mathrm{N}$ to creatinine (Table 4 ). There were no differences in the ratio of purine derivatives (PD) to creatinine. Blood concentrations of BHBA were elevated in $\mathrm{CON}$ and $\mathrm{Sg}$ cows, but similar among the other treatments. Blood NEFA concentrations were greater $(P<0.05)$ in cows fed the $\mathrm{Sg}$ and $\mathrm{FbN}$ treatments, but similar among the other treatments. 
Table 3. Effects of supplementing different carbohydrate types to grazing dairy cows in early lactation on milk yield and milk composition

\begin{tabular}{|c|c|c|c|c|c|c|c|}
\hline \multirow[b]{2}{*}{ Item } & \multicolumn{5}{|c|}{$\operatorname{Diet}^{1}$} & \multirow[b]{2}{*}{$\mathrm{SED}^{2}$} & \multirow[b]{2}{*}{$P$-value ${ }^{3}$} \\
\hline & $\mathrm{CON}$ & St & StN & $\mathrm{FbN}$ & $\mathrm{Sg}$ & & \\
\hline \multicolumn{8}{|l|}{ Yield (kg/d) } \\
\hline Milk & 23.1 & 27.7 & 25.5 & 26.2 & 23.6 & 1.34 & 0.005 \\
\hline Fat & 1.03 & 1.07 & 1.11 & 1.16 & 1.06 & 0.061 & 0.33 \\
\hline $\mathrm{TP}^{4}$ & 0.74 & 0.95 & 0.85 & 0.87 & 0.73 & 0.038 & $<0.001$ \\
\hline Lactose & 1.13 & 1.38 & 1.25 & 1.28 & 1.14 & 0.063 & 0.001 \\
\hline \multicolumn{8}{|c|}{ Milk composition (\%) } \\
\hline Fat & 4.44 & 3.88 & 4.39 & 4.41 & 4.57 & 0.209 & 0.016 \\
\hline $\mathrm{TP}$ & 3.20 & 3.43 & 3.34 & 3.34 & 3.11 & 0.075 & 0.001 \\
\hline Lactose & 4.89 & 4.99 & 4.91 & 4.92 & 4.85 & 0.037 & 0.010 \\
\hline MUN (mmol/L) & 7.24 & 5.10 & 7.09 & 6.40 & 6.60 & 0.228 & $<0.001$ \\
\hline
\end{tabular}

${ }^{1} \mathrm{CON}=$ control (pasture only); $\mathrm{St}=$ pasture with a starch-based supplement; StN = pasture with a starchbased supplement and additional $\mathrm{N} ; \mathrm{FbN}=$ pasture with a fiber-based supplement and additional $\mathrm{N} ; \mathrm{Sg}=$ pasture with a sugar-based supplement.

${ }^{2}$ Standard error of the difference.

${ }^{3}$ Refers to the overall treatment effect. The least significant difference for this study was $2 \times$ SED. Therefore, individual treatment means were considered significantly different when they differed by $>2 \times$ SED.

${ }^{4} \mathrm{TP}=$ true protein .

\section{CNCPS Predictions}

Predictions from the CNCPS are presented in Table 2. Metabolizable energy and MP intake was similar among the St and FbN treatments and $\mathrm{Sg}$ and $\mathrm{StN}$ treatments, respectively, but predicted MP allowable milk was considerably higher than ME allowable milk. Cows fed the StN and $\mathrm{FbN}$ diets were similar in total $\mathrm{N}$ intake $(\sim 600 \mathrm{~g}$ of $\mathrm{N} / \mathrm{d})$, which was approximately $100 \mathrm{~g}$ greater than for those fed the St and Sg diets and $70 \mathrm{~g}$ greater than the CON. When tissue mobilization was included in the model, predicted ME and MP allowable milk were balanced and similar to actual milk production.
Predicted urinary $\mathrm{N}$ excretion followed the trends evident in ratios of urinary $\mathrm{N}$ and urinary urea to creatinine (Table 4 ). The ratios of productive N:urinary $\mathrm{N}$, productive N:intake $\mathrm{N}$, and milk TP:MP supply were all greater in cows fed the St diet, but similar among those fed the other diets.

\section{DISCUSSION}

Efficiency of $\mathrm{N}$ utilization in dairy cows is typically low, averaging around $25 \%$, but can range from 15 to $40 \%$ (Calsamiglia et al., 2010). Trends evaluated over a wide range of dietary and management conditions

Table 4. Effects of supplementing different carbohydrate types to grazing dairy cows in early lactation on parameters of $\mathrm{N}$ and energy metabolism

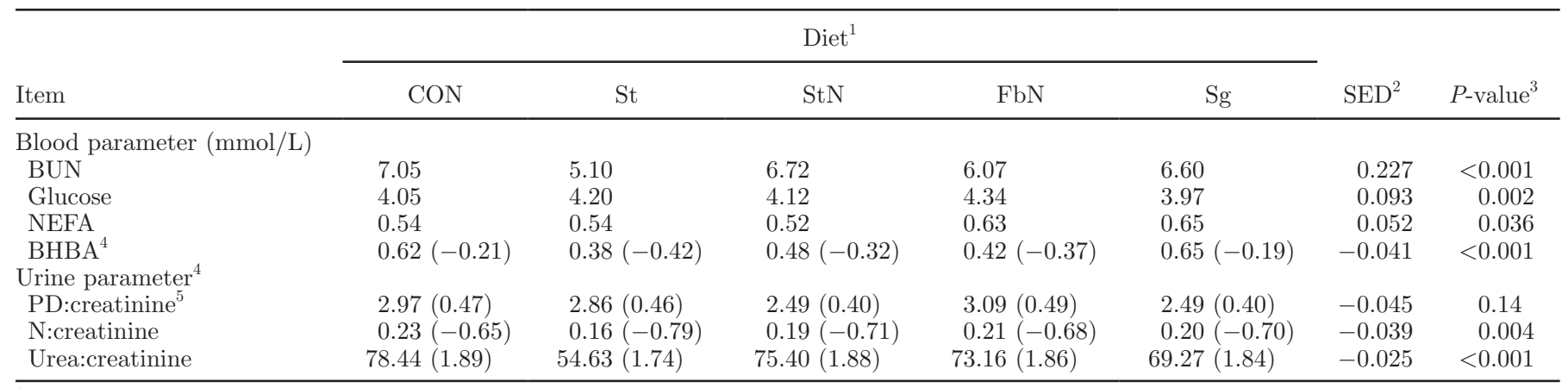

${ }^{1} \mathrm{CON}=$ control (pasture only); $\mathrm{St}=$ pasture with a starch-based supplement; $\mathrm{StN}=$ pasture with a starch-based supplement and additional N; $\mathrm{FbN}=$ pasture with a fiber-based supplement and additional $\mathrm{N} ; \mathrm{Sg}=$ pasture with a sugar-based supplement.

${ }^{2}$ Standard error of the difference.

${ }^{3}$ Refers to the overall treatment effect. The least significant difference for this study was $2 \times$ SED. Therefore, individual treatment means were considered significantly different when they differed by $>2 \times$ SED.

${ }^{4}$ Data were logarithm transformed for statistical analysis. Numbers outside the parentheses are back-transformed values and numbers inside the parentheses are logarithm transformed. The SED corresponds to the transformed values.

${ }^{5} \mathrm{PD}=$ purine derivatives (allantoin + uric acid). 
indicate that dietary $\mathrm{CP}$ concentration is the most important factor influencing the efficiency of $\mathrm{N}$ use (Huhtanen and Hristov, 2009). Efficiencies as high as 43\% (Frank and Swensson, 2002) and 37\% (Noftsger and St-Pierre, 2003) have been reported in the literature in TMR-fed cows and as high as 38\% in cows fed ryegrass-based diets (Moorby et al., 2006). The observed $\mathrm{N}$ efficiencies for cows in the current study ranged from 22 to $29 \%$ (Table 2), which, according to Calsamiglia et al. (2010), would be classified as ranging from low to moderately high, respectively. Cows with the highest $\mathrm{N}$-use efficiency in the current study (St) still wasted $10 \%$ more $\mathrm{N}$ than cows in the study of Moorby et al. (2006). The major difference between the 2 studies was the CP content of the pasture, which was $28.1 \%$ in the current study (Table 1) compared with approximately $10 \%$ in the study of Moorby et al. (2006). Attempts have been made to improve the retention of dietary $\mathrm{N}$ by synchronizing the supply of energy and protein in the rumen through supplementation (Kolver et al., 1998a), and also through feeding pasture cultivars bred to have higher sugar content (Edwards et al., 2007). Effects have generally been transient, with no real improvement in $\mathrm{N}$ utilization, suggesting that $\mathrm{N}$ intake is a more important factor in improving $\mathrm{N}$ utilization (Henning et al., 1993; Kolver et al., 1998a; Kim et al., 1999; Edwards et al., 2007).

Pasture CP in the current study was higher than anticipated (Table 1); this resulted in predicted MPallowable milk being approximately $10 \mathrm{~kg}$ higher than ME-allowable milk (ME- and MP-allowable milk refer to the potential milk that could be produced at the predicted supply of ME and MP by the CNCPS; Table 2). Unfortunately, the StN treatment was less palatable than the other treatments and resulted in lower-thanformulated ME intake. Despite this, $\mathrm{N}$ intake and predicted MP-allowable milk were similar among cows fed the St and $\mathrm{Sg}$ treatments and $\mathrm{StN}$ and $\mathrm{FbN}$ treatments (Table 2) allowing the comparison of both dietary $\mathrm{N}$ dilutions and the effect of carbohydrate type. Compared with the $\mathrm{CON}$, cows fed the Sg diet had a lower ratio of urinary urea:creatinine and MUN; however, urinary $\mathrm{N}$ :creatinine and BUN were similar. This suggests a small $\mathrm{N}$ dilution effect consistent with the reduction in dietary $\mathrm{N}$ intake (Table 2), but no improvements in the overall efficiency of $\mathrm{N}$ use. In contrast, cows fed the St diet consumed the same amount of dietary $\mathrm{N}$ as those fed the $\mathrm{Sg}$ diet, but had a 0.06-U greater N-use efficiency (Table 2). Cows fed the St diet consumed more $\mathrm{ME}$ than those fed the Sg diet. However, cows fed the Sg diet also consumed more ME than the CON and no difference in production existed between these 2 treatments. Supplementing with sucrose has previously been reported to decrease rumen $\mathrm{pH}$ and decrease the rate of
NDF digestion (Huhtanen and Khalili, 1991; Chamberlain et al., 1993). In the experiment of Huhtanen and Khalili (1991), cows were fed $1 \mathrm{~kg}$ of DM/d of sucrose, which reduced the rate of NDF digestion by $1.5 \% / \mathrm{h}$. Pasture NDF in the current study was calculated to digest at a rate of $7 \% / \mathrm{h}$ (Van Amburgh et al., 2003). Reducing this digestion rate from 7 to $5.5 \% / \mathrm{h}$ in the CNCPS reduced the ME-allowable milk from 26 to 24 $\mathrm{kg}$ and probably explains the lack of response in the Sg treatment. Pasture in the current study was $12.8 \%$ sugar and the administration of molasses increased the sugar content in the diet of the Sg cows to $21.8 \%$ (Table 1). No difference was observed in the ratio of PD:creatinine, suggesting that total microbial growth was not changed by treatment (Valadares et al., 1999), although a tendency was observed for PD:creatinine to be lower in $\mathrm{Sg}$ and StN cows. Therefore, supplementing molasses to cows consuming high-quality spring pasture using the method used in the current experiment (1.5 $\mathrm{kg} / \mathrm{d}$ split in 2 feeds at milking) has no production benefit.

The effect of supplementing a fermentable fiber source was also investigated $(\mathrm{FbN})$ and compared with supplementing starch ( $\mathrm{StN}$ and $\mathrm{St}$ ). Cows fed the FbN diet had lower BUN and MUN concentrations than cows fed the StN diet; however, no differences existed in $\mathrm{N}$ excretion (Table 4) or predicted $\mathrm{N}$ utilization (Table 2). Numerically, cows fed the St diet produced more milk protein than cows fed the FbN diet. Rius et al. (2010) reported increased milk protein synthesis with the addition of postruminal starch, a result, most likely, of increased concentrations of insulin and IGF-1 (Griinari et al., 1997; Mackle et al., 1999; Rius et al., 2010). In the current study, differences in N excretion among treatments could be largely explained by differences in $\mathrm{N}$ intake (Table 2), with only subtle differences in productive $\mathrm{N}$ when $\mathrm{ME}$ intake was similar. When comparing the St and $\mathrm{FbN}$ treatments, approximately $90 \%$ of the difference in $\mathrm{N}$ excretion could be attributed to a reduction in $\mathrm{N}$ intake, whereas $10 \%$ could be attributed to higher productive $\mathrm{N}$ output. These findings are in agreement with the conclusion of Huhtanen and Hristov (2009) that reducing $\mathrm{N}$ intake is the most important factor in reducing $\mathrm{N}$ losses from dairy operations.

Predictions from the CNCPS suggest that cows were consuming adequate dietary MP at the given level of milk, but dietary ME was limited; this is similar to the results of Kolver et al. (1998b). A major difficulty when conducting grazing studies is accurately estimating DMI (Bargo et al., 2003). Intakes reported in this study (Table 2) are based on the $n$-alkane technique described by Kennedy et al. (2003). The dosing and sampling period for this assay coincided with a period 
of prolonged wet weather, which reduced pasture utilization and probably explains the low pasture DMI (Holmes et al., 2002). However, pasture intake could also have been underestimated if the recovery of dosed C32 n-alkane was lower than expected (Kennedy et al. 2003). Blood NEFA increased sharply and BW decreased sharply over this period (data not presented), which is consistent with the ME deficit predicted by the CNCPS. The model predicted cows fed the Sg and the CON diets to be most limited in dietary ME intake compared with milk produced, which is consistent with higher concentrations of BHBA (Table 4). Mobilization of tissue accounted for $36 \%$ of the ME requirement for cows fed the CON diet, which is comparable to levels reported from cows in the first 3 wk of lactation, but are high for cows in the fifth week of lactation (Komaragiri and Erdman, 1997; Pedernera et al., 2008). Including the recorded change in BW into the CNCPS aligned predicted ME and MP milk closely with actual milk for all treatments (Table 2) and is consistent with previous evaluations of the CNCPS under grazing conditions (Kolver et al., 1998b). Predictions of $\mathrm{N}$ excretion reflect measured N excretion (Table 4). Cows fed the St diet were predicted to excrete $70 \mathrm{~g} / \mathrm{d}$ less urinary $\mathrm{N}$ than the CON and approximately $100 \mathrm{~g} / \mathrm{d}$ less than cows fed the StN and FbN diets, respectively. Although $70 \mathrm{~g} / \mathrm{d}$ may seem inconsequential, in a herd of 1,000 cows, this reduction is equivalent to $1,000 \mathrm{~kg}$ less urea excreted per week and, if sustained, represents a considerable reduction in N loss to the environment. Similar effects could be achieved if $\mathrm{CP}$ levels in pasture were reduced (Moorby et al., 2006). Given that only 1 data point was modeled per treatment, care must be taken when interpreting these results. However, model predictions were consistent with the recorded data and suggest that the CNCPS can be successfully used as a tool to formulate diets to improve $\mathrm{N}$ utilization in grazing cows.

\section{CONCLUSIONS}

Nitrogen utilization can be improved by including high-energy, low-protein supplements into the diets of grazing dairy cows. Reducing dietary $\mathrm{N}$ intake appears to be the most important factor in improving $\mathrm{N}$ utilization when ME intake is the same. However, subtle improvements in milk protein output can be achieved by feeding starch-, compared with fiber- or sugar-based supplements. Feeding additional sugar to cows fed high-quality spring pasture had no real benefit in the current study. Predictions from the CNCPS were consistent with measured data and predicted ME- and MP-allowable milk were close to measured milk production when estimations of tissue mobilization were included. Predictions of $\mathrm{N}$ utilization also reflected the measured data, indicating that the CNCPS is a useful tool in formulating diets to reduce $\mathrm{N}$ losses to the environment.

\section{ACKNOWLEDGMENTS}

The authors acknowledge the financial support of New Zealand dairy farmers, through DairyNZ Inc. (Hamilton, New Zealand; project no. AN803), and the Ministry of Agriculture and Forestry (Wellington, New Zealand) through the Sustainable Farming Fund (project no. 08/012). Financial support for R. J. Higgs was provided in partnership by DairyNZ and Adisseo (Commentry, France). The assistance of the DairyNZ technical team, farm staff on Lye Farm, and the statistical expertise of Barbara Dow (Dairy NZ) are also gratefully acknowledged.

\section{REFERENCES}

Barbano, D. M., J. M. Lynch, and J. R. Fleming. 1991. Direct and indirect determination of true protein-content of milk by Kjeldahl analysis: Collaborative study. J. AOAC 74:281-288.

Bargo, F., L. D. Muller, E. S. Kolver, and J. E. Delahoy. 2003. Invited review: Production and digestion of supplemented dairy cows on pasture. J. Dairy Sci. 86:1-42.

Bauman, D. E., C. L. Davis, and H. F. Bucholtz. 1971. Propionate production in the rumen of cows fed either a control or high-grain, low-fiber diet. J. Dairy Sci. 54:1282-1287.

Beckman, J. L., and W. P. Weiss. 2005. Nutrient digestibility of diets with different fiber to starch ratios when fed to lactating dairy cows. J. Dairy Sci. 88:1015-1023.

Broderick, G. A. 2003. Effects of varying dietary protein and energy levels on the production of lactating dairy cows. J. Dairy Sci. 86:1370-1381.

Calsamiglia, S., A. Ferret, C. K. Reynolds, N. B. Kristensen, and A. M. van Vuuren. 2010. Strategies for optimizing nitrogen use by ruminants. Animal 4:1184-1196.

Cant, J. P., R. Berthiaume, H. Lapierre, P. H. Luimes, B. W. McBride, and D. Pacheco. 2003. Responses of the bovine mammary glands to absorptive supply of single amino acids. Can. J. Anim. Sci. 83:341-355.

Chamberlain, D. G., S. Robertson, and J.-J. Choung. 1993. Sugars versus starch as supplements to grass silage: Effects on ruminal fermentation and the supply of microbial protein to the small intestine, estimated from the urinary excretion of purine derivatives, in sheep. J. Sci. Food Agric. 63:189-194.

da Fonseca-Wollheim, F. 1973. Significance of hydrogen-ion concentration and addition of ADP in determination of ammonia with glutamate dehydrogenase - An improved enzymic determination of ammonia. 1. Z. Klin. Chem. Klin. Biochem. 11:421-425.

Dalley, D. E., J. R. Roche, C. Grainger, and P. J. Moate. 1999. Dry matter intake, nutrient selection and milk production of dairy cows grazing rainfed perennial pastures at different herbage allowances in spring. Aust. J. Exp. Agric. 39:923-931.

Edwards, G. R., A. J. Parsons, and S. Rasmussen. 2007. High sugar grasses for dairy systems: Meeting the challenges for pasture-based dairying. Pages 307-334 in Proc. Australasian Dairy Science Symposium, University of Melbourne, Victoria, Australia. National Dairy Alliance, Victoria, Australia

Ferguson, J. D., D. T. Galligan, and N. Thomsen. 1994. Principal descriptors of body condition score in Holstein cows. J. Dairy Sci. $77: 2695-2703$.

Fox, D. G., L. O. Tedeschi, T. P. Tylutki, J. B. Russell, M. E. Van Amburgh, L. E. Chase, A. N. Pell, and T. R. Overton. 2004. The 
Cornell Net Carbohydrate and Protein System model for evaluating herd nutrition and nutrient excretion. Anim. Feed Sci. Technol. 112:29-78.

Fox, D. G., M. E. Van Amburgh, and T. P. Tylutki. 1999. Predicting requirements for growth, maturity, and body reserves in dairy cattle. J. Dairy Sci. 82:1968-1977.

Frank, B., and C. Swensson. 2002. Relationship between content of crude protein in rations for dairy cows and milk yield, concentration of urea in milk and ammonia emissions. J. Dairy Sci. 85:1829-1838.

Griinari, J. M., M. A. McGuire, D. A. Dwyer, D. E. Bauman, D. M. Barbano, and W. A. House. 1997. The role of insulin in the regulation of milk protein synthesis in dairy cows. J. Dairy Sci. 80:2361-2371.

Hanigan, M. D., B. J. Bequette, L. A. Crompton, and J. France. 2001. Modeling mammary amino acid metabolism. Livest. Prod. Sci. 70:63-78.

Henning, P. H., D. G. Steyn, and H. H. Meissner. 1993. Effect of synchronization of energy and nitrogen supply on ruminal characteristics and microbial growth. J. Anim. Sci. 71:2516-2528.

Higgs, R. J., L. E. Chase, and M. E. Van Amburgh. 2012. Development and evaluation of equations in the Cornell Net Carbohydrate and Protein System to predict nitrogen excretion in lactating dairy cows. J. Dairy Sci. 95:2004-2014.

Holmes, C. W., I. M. Brookes, D. J. Garrick, T. J. Mackenzie, T. J. Parkinson, and G. F. Wilson. 2002. Milk production from pasture-Principles and Practices. Massey University, Palmerston North, New Zealand.

Hoogendoorn, C. J., C. W. Holmes, and A. C. P. Chu. 1992. Some effects of herbage composition, as influenced by previous grazing management, on milk production by cows grazing on ryegrass/ white clover pastures. 2. Milk production in late spring/summer: Effects of grazing intensity during the preceding spring period. Grass Forage Sci. 47:316-325.

Huhtanen, P., and A. N. Hristov. 2009. A meta-analysis of the effects of dietary protein concentration and degradability on milk protein yield and milk $\mathrm{N}$ efficiency in dairy cows. J. Dairy Sci. 92:3222-3232.

Huhtanen, P., and H. Khalili. 1991. Sucrose supplements in cattle given grass silage-based diet. 3. Rumen pool size and digestion kinetics. Anim. Feed Sci. Technol. 33:275-287.

IDF (International Dairy Federation). 1987. Milk: Determination of fat content-Röese Gottlieb gravimetric method (reference method). IDF Standard FIL-IDF. Vol. 1C. IDF, Brussels, Belgium.

Kennedy, J., P. Dillon, L. Delaby, P. Faverdin, G. Stakelum, and M. Rath. 2003. Effect of genetic merit and concentrate supplementation on grass intake and milk production with Holstein Friesian dairy cows. J. Dairy Sci. 86:610-621.

Kim, K. H., Y.-G. Oh, J.-J. Choung, and D. G. Chamberlain. 1999. Effects of varying degrees of synchrony of energy and nitrogen release in the rumen on the synthesis of microbial protein in cattle consuming grass silage. J. Sci. Food Agric. 79:833-838.

Kolver, E., L. D. Muller, G. A. Varga, and T. J. Cassidy. 1998a. Synchronization of ruminal degradation of supplemental carbohydrate with pasture nitrogen in lactating dairy cows. J. Dairy Sci. 81:2017-2028.

Kolver, E. S. 2003. Nutritional limitations to increased production on pasture-based systems. Proc. Nutr. Soc. 62:291-300.

Kolver, E. S., L. D. Muller, M. C. Barry, and J. W. Penno. 1998b. Evaluation and application of the Cornell Net Carbohydrate and Protein System for dairy cows fed diets based on pasture. J. Dairy Sci. 81:2029-2039.

Komaragiri, M. V. S., and R. A. Erdman. 1997. Factors affecting body tissue mobilization in early lactation dairy cows. 1. Effect of dietary protein on mobilization of body fat and protein. J. Dairy Sci. 80:929-937.

Lapierre, H., R. Berthiaume, G. Raggio, M. C. Thivierge, L. Doepel, D. Pacheco, P. Dubreuil, and G. E. Lobley. 2005. The route of absorbed nitrogen into milk protein. Anim. Sci. 80:10-22.

Lapierre, H., and G. E. Lobley. 2001. Nitrogen recycling in the ruminant: A review. J. Dairy Sci. 84(Suppl.):E233-E236.
Ledgard, S. F., J. W. Penno, and M. S. Sprosen. 1999. Nitrogen inputs and losses from clover/grass pastures grazed by dairy cows, as affected by nitrogen fertilizer application. J. Agric. Sci. 132:215225

Lee, J. M., D. J. Donaghy, and J. R. Roche. 2008. Short communication: Effect of postgrazing residual pasture height on milk production. J. Dairy Sci. 91:4307-4311.

Mackle, T. R., D. A. Dwyer, K. L. Ingvartsen, P. Y. Chouinard, J. M. Lynch, D. M. Barbano, and D. E. Bauman. 1999. Effects of insulin and amino acids on milk protein concentration and yield from dairy cows. J. Dairy Sci. 82:1512-1524.

Marini, J. C., and M. E. Van Amburgh. 2003. Nitrogen metabolism and recycling in Holstein heifers. J. Anim. Sci. 81:545-552.

Mayes, R. W., C. S. Lamb, and P. M. Colgrove. 1986. The use of dosed and herbage n-alkanes as markers for the determination of herbage intake. J. Agric. Sci. 107:161-170.

Miller, L. A., J. M. Moorby, D. R. Davies, M. O. Humphreys, N. D. Scollan, J. C. MacRae, and M. K. Theodorou. 2001. Increased concentration of water-soluble carbohydrate in perennial ryegrass (Lolium perenne L.): Milk production from late-lactation dairy cows. Grass Forage Sci. 56:383-394.

Moorby, J. M., R. T. Evans, N. D. Scollan, J. C. MacRae, and M. K. Theodorou. 2006. Increased concentration of water-soluble carbohydrate in perennial ryegrass (Lolium perenne L.). Evaluation in dairy cows in early lactation. Grass Forage Sci. 61:52-59.

Noftsger, S., and N. R. St-Pierre. 2003. Supplementation of methionine and selection of highly digestible rumen undegradable protein to improve nitrogen efficiency for milk production. J. Dairy Sci. 86:958-969.

Pedernera, M., S. C. García, A. Horagadoga, I. Barchia, and W. J. Fulkerson. 2008. Energy balance and reproduction on dairy cows fed to achieve low or high milk production on a pasture-based system. J. Dairy Sci. 91:3896-3907.

Rius, A. G., J. A. D. R. N. Appuhamy, J. Cyriac, D. Kirovski, O. Becvar, J. Escobar, M. L. McGilliard, B. J. Bequette, R. M. Akers, and M. D. Hanigan. 2010. Regulation of protein synthesis in mammary glands of lactating dairy cows by starch and amino acids. J. Dairy Sci. 93:3114-3127.

Roche, J. R., P. Dillon, S. Crosse, and M. Rath. 1996. The effect of closing date of pasture in autumn and turnout date in spring on sward characteristics, dry matter yield and milk production of spring-calving dairy cows. Ir. J. Agric. Food Res. 35:127-140.

Roche, J. R., P. G. Dillon, C. R. Stockdale, L. H. Baumgard, and M. J. VanBaale. 2004. Relationships among international body condition scoring systems. J. Dairy Sci. 87:3076-3079.

Sairanen, A., H. Khalili, J. I. Nousiainen, S. Ahvenjärvi, and P. Huhtanen. 2005. The effect of concentrate supplementation on nutrient flow to the omasum in dairy cows receiving freshly cut grass. J. Dairy Sci. 88:1443-1453.

Tylutki, T. P., D. G. Fox, V. M. Durbal, L. O. Tedeschi, J. B. Russell, M. E. Van Amburgh, T. R. Overton, L. E. Chase, and A. N. Pell. 2008. Cornell Net Carbohydrate and Protein System: A model for precision feeding of dairy cattle. Anim. Feed Sci. Technol. 143:174-202.

Valadares, R. F. D., G. A. Broderick, S. C. V. Filho, and M. K. Clayton. 1999. Effect of replacing alfalfa silage with high moisture corn on ruminal protein synthesis estimated from excretion of total purine derivatives. J. Dairy Sci. 82:2686-2696.

Van Amburgh, M. E., L. E. Chase, T. R. Overton, D. A. Ross, E. B. Recktenwald, R. J. Higgs, and T. P. Tylutki. 2010. Updates to the Cornell Net Carbohydrate and Protein System v6.1 and implications for ration formulation. Pages 144-159 in Proc. Cornell Nutrition Conf., Syracuse, NY. Department of Animal Science, Cornell University, Ithaca, NY.

Van Amburgh, M. E., E. B. Recktenwald, D. A. Ross, T. R. Overton, and L. E. Chase. 2007. Achieving better nitrogen efficiency in lactating dairy cattle: Updating field usable tools to improve nitrogen efficiency. Pages 25-38 in Proc. Cornell Nutrition Conf., Syracuse, NY. Department of Animal Science, Cornell University, Ithaca, NY. 
Van Amburgh, M. E., P. J. Van Soest, J. B. Robertson, and W. F. Knaus. 2003. Corn silage neutral detergent fiber: Refining a mathematical approach for in vitro rates of digestion. Pages 99-108 in Proc. Cornell Nutr. Conf. Department of Animal Science, Cornell University, Ithaca, NY

VSN International. 2010. GenStat for Windows, 13th Edition. VSN International, Hemel Hempstead, UK.
Wildman, E. E., G. M. Jones, P. E. Wagner, R. L. Boman, H. F. Troutt Jr., and T. N. Lesch. 1982. A dairy cow body condition scoring system and its relationship to selected production characteristics. J. Dairy Sci. 65:495-501.

Young, E. G., and C. F. Conway. 1942. On the estimation of allantoin by the Rimini-Schryver reaction. J. Biol. Chem. 142:839-853. 